\title{
PIKE LAKE BUTTERFLY CENSUS 1986-1992
}

KEN PIVNICK, 209 - 7th Street East, Saskatoon, Saskatchewan. S7H OW9

The Xerces Society, an international, U.S.-based organization dedicated to the conservation of invertebrate species, initiated the annual Fourth of July North American Butterfly Count in 1975, patterning it after the highly successful North American Christmas Bird Count. The goals were to stimulate more public awareness and interest in insects and the effects of human-induced habitat change on them, as well as to collect data on major population trends of individual species. (The success of this last goal has been evaluated recently. ${ }^{5}$ ) I initiated a butterfly count at Pike Lake near Saskatoon in 1986. In 1990, Ron Hooper initiated a second one for the Prairie Provinces in Fort Qu'Appelle. By 1991, 145 butterfly counts were reported in Canada and the U.S. ${ }^{6}$

In 1986, I designated the central point of the 15-mile-diameter (24$\mathrm{km}$ ) circle of the Pike Lake count on the " $T$ " junction at the north end of Pike Lake. I have reported a count each year since, except in 1987 and 1991 when the weather was not conducive to butterfly counting (in 1987, I tried a second time with equally poor weather cooperation). Each year, I have had two to seven people assist me, making the count all the more productive. In this article I present the results of these counts to stimulate further interest in butterflies on the Prairies (Table 1).

The common names used here are from the Butterflies of Manitoba, ${ }^{3}$ or The Common Names of North American Butterflies ${ }^{4}$ where they are not listed in the first book. Corrections have been made to the species lists originally reported in the annual count reports published by the Xerces Society. ${ }^{*}$

Although called "Fourth of July" counts, they actually take place between June 13 and July 26 . The Pike Lake count has shifted from late July in 1986 and 1988, to early July from 1989 on, for reasons beyond my control. However, I intend to keep the present approximate period for comparability of data. There are some striking shifts in species presence as a result of the date shift. Most notably, Alfalfa Butterfly, Bronze Copper, Aphrodite Fritillary, and Common Wood Nymph were counted primarily in 1986-1988, as they are more commonly present in late than early July. Other butterflies, including Western Tailed Blue, White Admiral, Northwestern Fritillary, Ringlet, Long Dash, and Silver-

*My original identification errors were detected based on more experience, and on consultation with Ron Hooper of the Royal Saskatchewan Museum, Regina. In 1986 and 1988, we counted Northern Pearl Crescents, not "Pearl Crescents" as originally reported. In 1989, two "Northern Pearl Crescents" were actually Tawny Crescents. In 1986 and 1988, I recorded "Checkered Whites"; these were actually Western Checkered Whites, formerly considered separate subspecies, now considered separat species. 2,3 One "Spring Azure" in 1989 was actually a Silvery Blue; all "Tawny-edged Skippers" in 1989 were actually Garita Skippers. 
Table 1. BUTTERFLIES COUNTED IN PIKE LAKE CENSUS 1986-1992.

Butterfly species

Numbers collected

\begin{tabular}{|c|c|c|c|c|c|}
\hline & \\
\hline & $\begin{array}{c}\text { July } 27 \\
1986\end{array}$ & $\begin{array}{c}\text { July } 23 \\
1988 \\
\end{array}$ & $\begin{array}{c}\text { July } 9 \\
1989 \\
\end{array}$ & $\begin{array}{c}\text { July } 8 \\
1990 \\
\end{array}$ & $\begin{array}{c}\text { July } 4 \\
1992 \\
\end{array}$ \\
\hline \multicolumn{6}{|l|}{ True skippers } \\
\hline Silver-spotted Skipper & 0 & 0 & 1. & 3 & 7 \\
\hline Dreamy Dusky Wing & 0 & 0 & 0 & 0 & 1 \\
\hline Common Checkered Skipper & 0 & 0 & 0 & 6 & 0 \\
\hline Garita Skipper & 0 & 0 & 6 & 2 & 15 \\
\hline Long Dash & 0 & 0 & 3 & 4 & 6 \\
\hline Peck's Skipper & 0 & 0 & 1. & 0 & 2 \\
\hline \multicolumn{6}{|l|}{ Swallowtails } \\
\hline Tiger Swallowtail & 0 & 0 & 2. & 0 & 0 \\
\hline \multicolumn{6}{|l|}{ Whites and sulphurs } \\
\hline Cabbage White & 12 & 7 & 1 & 2 & 4 \\
\hline Western Checkered White & 32 & 21. & 0 & 16 & 21 \\
\hline Common Sulphur & 0 & 0 & 0 & 2 & 0 \\
\hline Queen Alexandra's Sulphur & 0 & 1. & 0 & $\underline{0}$ & 0 \\
\hline Alfalfa Butterfly & 34 & 66 & 0 & 0 & 0 \\
\hline \multicolumn{6}{|c|}{ Coppers, hairstreaks and blues } \\
\hline Bronze Copper & 3 & 3 & 0 & 0 & 0 \\
\hline Coral Hairstreak & 3 & 0 & 0 & 1. & 0 \\
\hline Acadian Hairstreak & 2 & 1 & 0 & 1 & 0 \\
\hline Spring Azure & 1 & 0 & 16 & 1. & 3 \\
\hline Melissa Blue & 0 & 42 & 0 & 10 & 1 \\
\hline Western Tailed Blue & 0 & 0 & 3 & 14 & 3 \\
\hline Greenish Blue & 0 & 0 & 0 & 1 & 0 \\
\hline Silvery Blue & 0 & 0 & 1 & 0 & 1 \\
\hline \multicolumn{6}{|l|}{ Brushfooted butterflies } \\
\hline Great Spangled Fritillary & 49 & 11 & 3 & 10 & 1 \\
\hline Aphrodite Fritillary & 1 & 6 & 0 & 0 & 0 \\
\hline Mormonia Fritillary & 0 & 2 & 1. & 0 & 0 \\
\hline Northwestern Fritillary & 0 & 0 & 2 & 6 & 6 \\
\hline Silver-bordered Fritillary & 3 & 0 & 10 & 15 & 0 \\
\hline Gorgone Checkerspot & 0 & 0 & 0 & 0 & 1 \\
\hline Northern Pearl Crescent & 31 & 9 & 26 & 36 & 40 \\
\hline Pearl Crescent & 0 & 0 & 0 & 0 & 1 \\
\hline Tawny Crescent & 0 & 2 & 2 & 0 & 0 \\
\hline Red Admiral & 0 & 0 & 1 & 1 & 1 \\
\hline Painted Lady & 0 & 1 & 0 & 1 & 11 \\
\hline Milbert's Tortoise Shell & 0 & 0 & 0 & 1 & 0 \\
\hline Satyr Anglewing & 0 & 0 & 0 & 1 & 0 \\
\hline Gray Comma & 0 & 0 & 3 & 0 & 0 \\
\hline Mourning Cloak & 0 & 0 & 1 & 0 & 0 \\
\hline White Admiral & 0 & 0 & 18 & 13 & 4 \\
\hline \multicolumn{6}{|l|}{ Satyrs and wood nymphs } \\
\hline Ringlet & 0 & 0 & 0 & 0 & 11 \\
\hline Common Wood Nymph & 58 & 42 & 0 & 3 & 0 \\
\hline \multicolumn{6}{|l|}{ Milkweed butterflies } \\
\hline Monarch & 0 & 0 & 0 & 0 & 1 \\
\hline Total Species & 12 & 14 & 19 & 23 & 21 \\
\hline Total Individuals & 229 & 214 & 101 & 150 & 141 \\
\hline
\end{tabular}


spotted, Garita and Peck's Skippers are more common in early July and were found mainly from 1989 on (early July is late for the Ringlet). In interpreting field guide flight periods for butterflies, it should be noted that butterflies with single generations are usually most abundant towards the beginning of the period.

The only unusual records to date from these counts are a slight northern range extension of the Acadian Hairstreak and a northern range extension of Queen Alexandra's Sulphur (collected by Blair Jarvis in 1988), previously found only in southwestern Saskatchewan and probably a stray.

Since some of our butterflies are very specific in their habitat needs and all habitats are not censused, and some species are present only at other times in the season (mainly earlier), the census has yielded only 39 of the approximately 75 species expected in the Saskatoon area, and generally half of that number in any one count. ${ }^{2}$ Greater participation in the future would allow a more thorough census of the designated area, which includes a great diversity of habitat, including poplar woods, wet meadows, sedge marshes, riverine sand flats, mixed prairie and sand hills. To date, I have been as faithful as possible to the same collecting sites.

Species identification was initially done only after collecting and pinning specimens. As my confidence and experience have grown, killing of specimens has become rare, and catching is frequently not necessary either, making the entire experience far more pleasant (especially for the butterflies!). With increasing experience by myself and two regular cocounters, Bernie Gollop and my wife, Kristina Komendant, more of the small, fast-flying, subtly coloured skipper species have been censused. I would encourage anyone interested to join one of the two Prairie butterfly counts, or to start up your own (please contact me for information). An annotated list of butterfly field guides relevant for Saskatchewan has been published recently. ${ }^{1}$

Acknowledgements Bernie Gollop and Ron Hooper made helpful suggestions on an earlier version of this manuscript.

1. GOLLOP, J.B. 1989. A selected, annotated bibliography for Saskatchewan butterfly watchers. Blue Jay 47:83-88.

2. HOOPER, R.R. 1986. Revised checklist of Saskatchewan butterflies. Blue Jay 44:154-163.

3. KLASSEN, P., A.R. WESTWOOD, W.B. PRESTON, and W.B. MCKILLOP. 1989. The butterflies of Manitoba. Manitoba Museum of Man and Nature, Winnipeg, Manitoba. 290 pp.

4. MILLER, J.Y. (ed.). 1992. The common names of North American butterflies. Smithsonian Institution Press, Washington, D.C. 177pp.

5. SWENGEL, A.B. 1990. Monitoring butterfly populations using the Fourth of July butterfly count. American Midland Naturalist 124:395-406.

6. SWENGEL, A.B., and P.A. OPLER (eds.). 1991. Fourth of July Butterfly Counts: 1991 report. Xerces Society, Portland, Oregon, 63pp. 